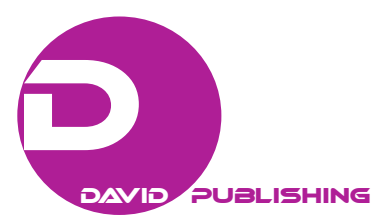

\title{
Health Tourism in Thermal Waters in Peshkopi, Albania-Statistical and Economic Analysis
}

\author{
Arif Murrja, Maksim Meço, Ilir Tomorri \\ Agriculture University of Tirana, Tirana, Albania
}

\begin{abstract}
Health tourism in thermal waters is one of the types of tourism in Albania. Attending these types of tourism, not only heals/cures some diseases of visitors/tourists, but also contributes to the economic development of the communities located near the thermal water resources. The purpose of the study is the identification of the comparative advantages of health tourism in the thermal waters, the Thermal Baths Peshkopi in Dibra, Albania. To realize this study we provided information by hotel businesses, owners of hostels and Balnear State Enterprise, which operate in the service of visitors/tourists who frequent health tourism thermal waters. The study showed: (i) The ratio Albanian tourists (domestic) and foreign tourists is 2:3; (ii) Time attendance is 10-15 nights of staying; (iii) The cost of person in hotels, including accommodation, three meals, transport and entrance fees in spa tourism center are on average $€ 12$, while these costs in the hostels of the residents are on average $€ 8$; (iv) The number of hotels to accommodate visitors/tourists is over 10 with over 900 beds in total; (v) The number of hostels that offer family tourism is about 111 with the average number of beds 8-10/house with over 1000 beds; (vi) Total revenue from health tourism, for hotels and hostels for 2015 were $€ 132,000$, while the 10-year period (2006-2015) is $€ 1,004,102$.
\end{abstract}

Keywords: visitor/tourist, health tourism, thermal waters, income, hostels, cost, advantages

\section{Introduction}

Thermal waters are used for healing/curative effects since antiquity. In Albania there are several sources of thermal waters ${ }^{1}$, which are: Bilaj in Fush-Krujë; Elbasan Thermal Baths; Bënja in Përmet; Vernomeros, Postenan in Leskovik; and Thermal Baths in Peshkopi, in Dibër. Since the study is aimed at the development of health tourism in thermal waters in Dibër it should be also mentioned thermal waters in Banjisht and Kosovrast in Macedonia ${ }^{2}$. The thermal springs in Kosovrast and Banjisht are part of ethnographic Dibër which does not comply with current administrative boundaries (Frashëri, 2012, p. 11).

Attendance of health tourism in the thermal waters of visitors, not only healing/cure various diseases, but enables the recognition of historical and geographical tourism of the city, as one of the most interesting regions

Arif Murrja, prof. asoc., Dr., Faculty of Economics and Agribusiness, Agriculture University of Tirana, Tirana, Albania.

Maksim Meço, prof. asoc., Dr., Faculty of Economics and Agribusiness, Agriculture University of Tirana, Tirana, Albania.

Ilir Tomorri, Dr., Faculty of Economics and Agribusiness, Agriculture University of Tirana, Tirana, Albania.

Correspondence concerning this article should be addressed to Maksim Meço, Faculty of Economics and Agribusiness, Agriculture University of Tirana, Rr. Pajsi Vodica, Koder-Kamez, Tirana 1001, Albania.

$1 \mathrm{http}: / /$ www.hoteleriturizemalbania.al/2012/05/burimet-e-ujerave-termale-kurative-ne.html.

${ }^{2}$ Defining the borders of Albania by the Conference of Ambassadors in London in 1913, left out a part of the territory of Dibër once the administrative part of the former Yugoslav today Republic of Macedonia. 
of Albania (Murrja, Meço, \& Tomorri, 2016). Development of tourism in the thermal waters in Peshkopi, Dibër increases the income of the hotel business, the owners of hostels, to agricultural businesses, the farmers, the budget of the Balnear State Enterprise and the municipal budget.

In Albania, before 90s the last century, health tourism thermal waters was owned by the state and offered primarily as medical service. In the early 90s the Albanian society moved from the centralized socialist economy to a free market economy. These political and economic changes enabled, not only private enterprise investment in construction of hotels, but residents in the adoption/adaptation of their homes in hostels, in view of the health tourism.

\section{Where Are the Thermal Baths of Peshkopia?}

Balnear complex healing/curative of the thermal waters in Peshkopi is administrated by the Balnear State Enterprise, which is subordinate to the Municipality of Dibër. This complex is located about two kilometers east of the city, to the right of the stream flow of Bellova, down the ridge to Deshatit. There are two sulphurous springs with temperatures from 35 to $43.5{ }^{0} \mathrm{C}$ with a flow of 14 liters/sec, derived from formations of gypsum Korab Mount and potassium sulfate content. Thermal Baths in Peshkopi are the rarest in the world for their healing power.

\section{The Study Area}

The study included: (i) tourism hotel service and family tourism on Llixha neighborhood in the city of Peshkopi; (ii) albanian visitors and foreign tourists; (iii) Visitors/dialy tourists from districts Dibër, Burrel, and Bulqizë; (iv) Balnear State Enterprise.

\section{The Purpose of the Study}

The purpose of the study is to inform visitors/tourists of thermal waters: (i) the value of rare healing/curative; (ii) the minimum cost of accommodation/food and transportation; (iii) the value of specific historical, geographic, gastronomic tourism etc.; (iv) the quality of service, hospitality, generosity, and communication. Also, through the SWOT analysis we will evaluate the strengths, weaknesses, opportunities, and threats of health tourism in Thermal Baths of Peshkopia.

\section{Objectives of the Study}

Objectives of the study for the period of 10 years (2006-2015) are: (i) statistical analysis of the number of domestic tourists and foreign tourists; (ii) statistical analysis of the geographical distribution of domestic tourists and foreign tourists; (iii) statistical analysis of the number of tourists/visitors in years; (iv) statistical analysis of the number of beds in hotels and hostels; (v) statistical analysis of revenue for hotel businesses and owners of hostels over the years and for the period 2006-2015; (vi) assessment by visitors/tourists perception the hospitality, service, accommodation, food, communication, etc.; (vii) cost of daily analysis per person; (viii) valuation by SWOT analysis.

\section{Literature Review}

The oldest archaeological facts and historicalfor thermal baths in Dibër points to the existence of two ancient pools nearby Banjisht Hotel. They were reconstructed in 1797 and have been restored recently by an entrepreneur named Capa, who is the only shareholder since acquisition or privatization in 2004 (http:/bdcapa.com/historia/). Even thermal therapy in Peshkopi Thermal Baths is very early, but organized tourist attendance dates too late. 
Based on the number of thermal springs, health tourism is one of the forms and types of tourism potentials, not only in Dibër, but also in Albania. And even if this country is rich in thermal water resources, health tourism thermal studies have been lacking. Therefore "thermal health tourism" is a new terminology, but in fact has begun to sensitize not only the tourism people attending, but also researchers tourist economy. Sensitization of tourists to attend health tourism thermal waters was due to the healing powers/curative thermal waters, while the interest of researchers aims measuring the impact of tourism in the economic development of the communities near these sources.

In statistical terms, the people attending health tourism thermal waters are called guests. All travelers who are involved in tourism are visitors. The term "visitor" represents the basic concept for the entire system of tourism statistics. The term "visitor" for statistical purposes and in accordance with the format of tourism classified in two categories: "tourists (visitors with overnights)" and "day visitors". Tourist is called a visitor, who spends at least one night in a hotel or guest house in the country that he visits, while daily visitor is a person who does not pass the night in a hotel or guesthouse in the country that he visits (INSTAT, Albania). Tourism comprises the activities of persons traveling to and staying in different places from the place of their usual residence for a period not longer than one calendar year (INSTAT, Albania) and the purpose of this trip is the passage of time free for tourism types different, for business, for official state services for sports and other activities. Also, in statistical terms, the adopted home for health tourism will call hostels.

\section{Methodology}

This study considers visitors of health tourism in thermal baths in Peshkopia district. To assess the hospitality, accommodations, food, service, information etc., we targeted a sample of 140 visitors/tourists, who are randomly selected and then interviewed. These interviews took place at five different hotels and seven hostels located in the in the targeted area. Interviews of visitors/tourists included in this sample were conducted at the "peak" period along 15 days, from 15 September to 1 October 2015.

To measure the reliability of the sample size is used the following formula:

$$
t=\frac{\bar{x}-\mu}{S / \sqrt{n}} \text { from where } \mu=\bar{x}-t \frac{S}{\sqrt{n}}
$$

$\mu-$ Overall data populating.

$\mathrm{X}$-Average selection (11.67).

$\mathrm{t}$ - The confidence level $(1-\alpha)=0.95$ and $\alpha=0.05$ security, where $\mathrm{Z} \alpha$ value $=1.96$.

$\mathrm{S}$-Variance of choice (2.47).

$\mathrm{n}$-Sample size (140).

To calculate the variance of selection is using the:

$$
S^{2}=\sum_{i=1}^{m} \frac{\left(x_{i}-\bar{x}\right)^{2}}{n-1} \text { from where } S=\sqrt{S^{2}} .
$$

$x_{i}$-The number of tourists interviewed from any hotel or hostels. 


\begin{tabular}{|l|l|l|l|l|l|}
\hline No. & Unit & $x_{i}$ & $\bar{x}$ & $\left(x_{i}-\bar{x}\right)$ & $\left(x_{i}-\bar{x}\right)^{2}$ \\
\hline 1 & Hotel no. 1 & 33 & 11.67 & 21.33 & 455 \\
\hline 2 & Hotel no. 2 & 15 & 11.67 & 3.33 & 11 \\
\hline 3 & Hotel no. 3 & 18 & 11.67 & 6.33 & 40 \\
\hline 4 & Hotel no. 4 & 16 & 11.67 & 4.33 & 19 \\
\hline 5 & Hotel no. 5 & 18 & 11.67 & 6.33 & 40 \\
\hline 6 & Hostels no. 1 & 4 & 11.67 & -7.67 & 59 \\
\hline 7 & Hostels no. 2 & 7 & 11.67 & -4.67 & 22 \\
\hline 8 & Hostels no. 3 & 2 & 11.67 & -9.67 & 94 \\
\hline 9 & Hostels no. 4 & 9 & 11.67 & $-2,67$ & 7 \\
\hline 10 & Hostels no. 5 & 6 & 11.67 & -5.67 & 32 \\
\hline 11 & Hostels no. 6 & 4 & 11.67 & -7.67 & 59 \\
\hline 12 & Hostels no. 7 & 8 & 11.67 & -3.67 & 13 \\
\hline No. of units $=12$ & $\mathrm{n}=140$ & $\bar{x}=140 / 12$ & & $\sum\left(x_{i}-\bar{x}\right)^{2}=851$ \\
\hline
\end{tabular}

Then, $S^{2}=851 / 139=6.12$ and $S=\sqrt{6.12}=2.47$.

By choosing the confidence level $(1-\alpha)=0.95$ we have, variance with tourist distribution $\mathrm{t}(\mathrm{n}-1)$ degrees of freedom, is that the value $t(n-1,0.05)$ completes the condition that the integral of $f(t, n-1)$ between $t(n-1,0.05)$ and $\mathrm{t}(\mathrm{n}-1,0.05)$ is 0.95 . In our study we have $0.95=$ Probability $\left[11.67-0.95^{*}(2.47 / 11.83)\right] \leq \mu \leq[11.67+$ $0.95 *(2.47 / 11.83)]$. So we $11.47 \leq \mu \leq 11.67$.

Besides sample of 140 visitors/tourists were interviewed five hotels adminstrator, seven hostels owners, and four Balnear state enterprise employees. To tourists mostly of questions are about the hospitality, accommodation, food, service, information, etc. And to administrators and business owners of guesthouses dominate questions are about the pleasure of tourists, the number of tourists who do not return, and why, the cost for staying, interest of visitors/tourists to recognize the historical and geographical tourism Dibër etc. And finally, to employees most of questions are where like: What is the period most frequented of the year in other words "peak", the average number of visitors per day during this period, the number of daily visitors, fees or charges on 20 position in the center minuata in the bathroom of spa tourism, medical services etc.

\section{Discussion of Data}

Accommodations of the tourists are hotels and hostels in the Llixha neighborhood in Peshkopi. The number of hotels to accommodate visitors/tourists is over 10 with over 900 beds in total, while the number of hostels is about 111 with an average number of beds 8-10 and total number of beds in the 1,000. For easier understanding, interpreting statistical data is used circular diagram in percentage and histogram in absolute value (Giorne \& Salvemini, 2003, pp. 91-92).

(1) Number of Albanian visitors/tourists is $40 \%$, while of foreign tourists is $60 \%$. The ratio is two to three domestic tourists.

Domestic visitors Albanian come mainly from Shkodra, Tirana, Durrësi, while foreigners from Kosova and Macedonia.

(2) Distribution of domestic tourists and foreign tourists (Kosova and Macedonia).

From Figure 2, we conclude that the geographic distribution of visitors/foreign tourists is: Kosova and Macedonia by $30 \%$, while domestic tourists are: Shkodra 20\%, Tirana 10\%, Durrësi 5\%, and other domestic 
$5 \%$.

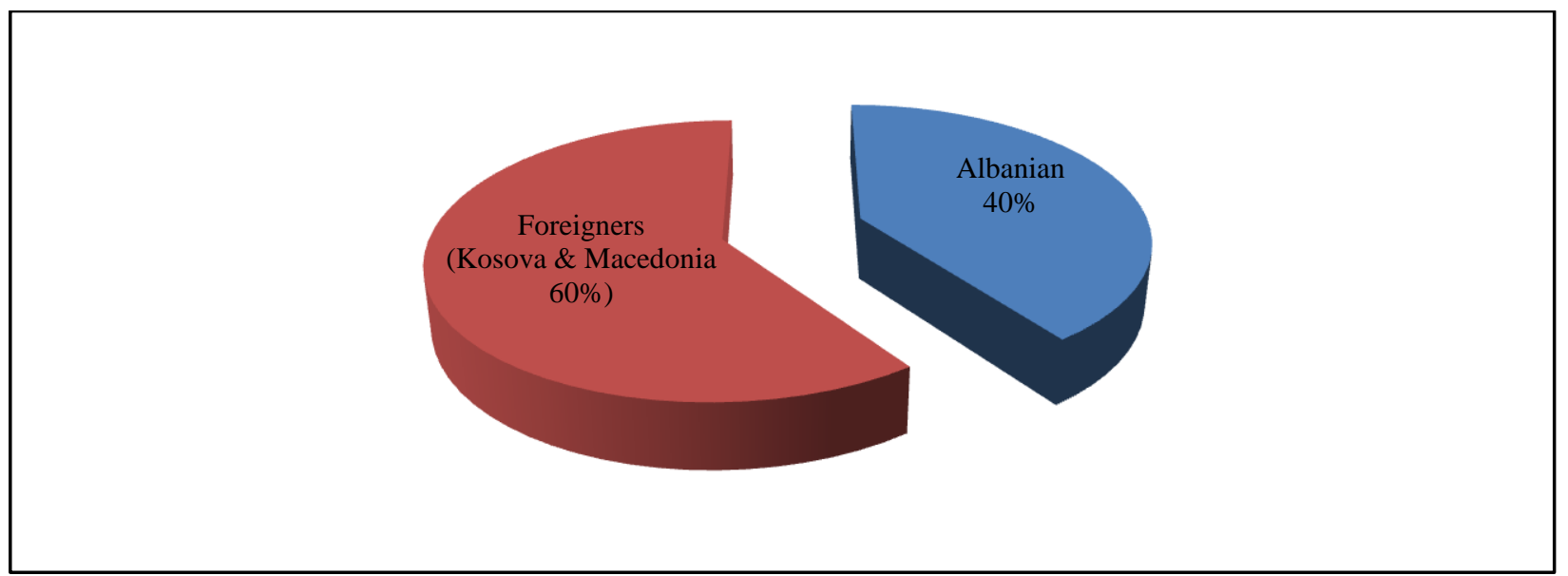

Figure 1. Report of Albanian tourists/foreign tourists.

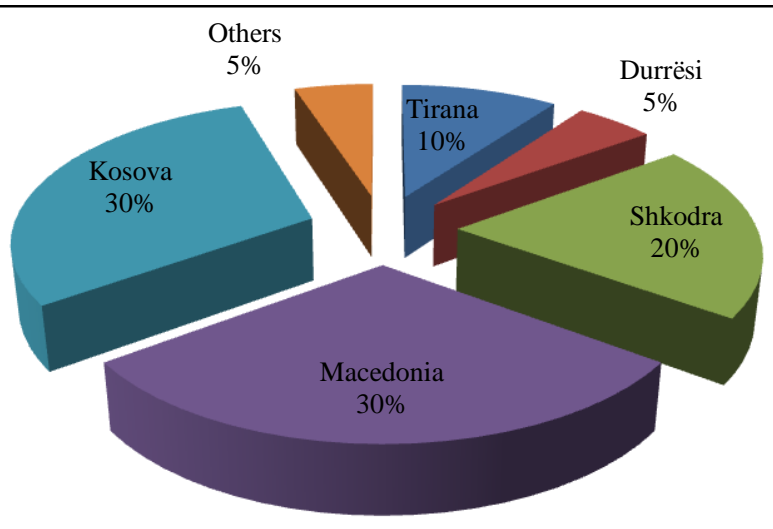

Figure 2. Geographical distribution of the visitors on percentage.

(3) Hospitality, service, accommodation, food etc., according visitors/tourists perception.
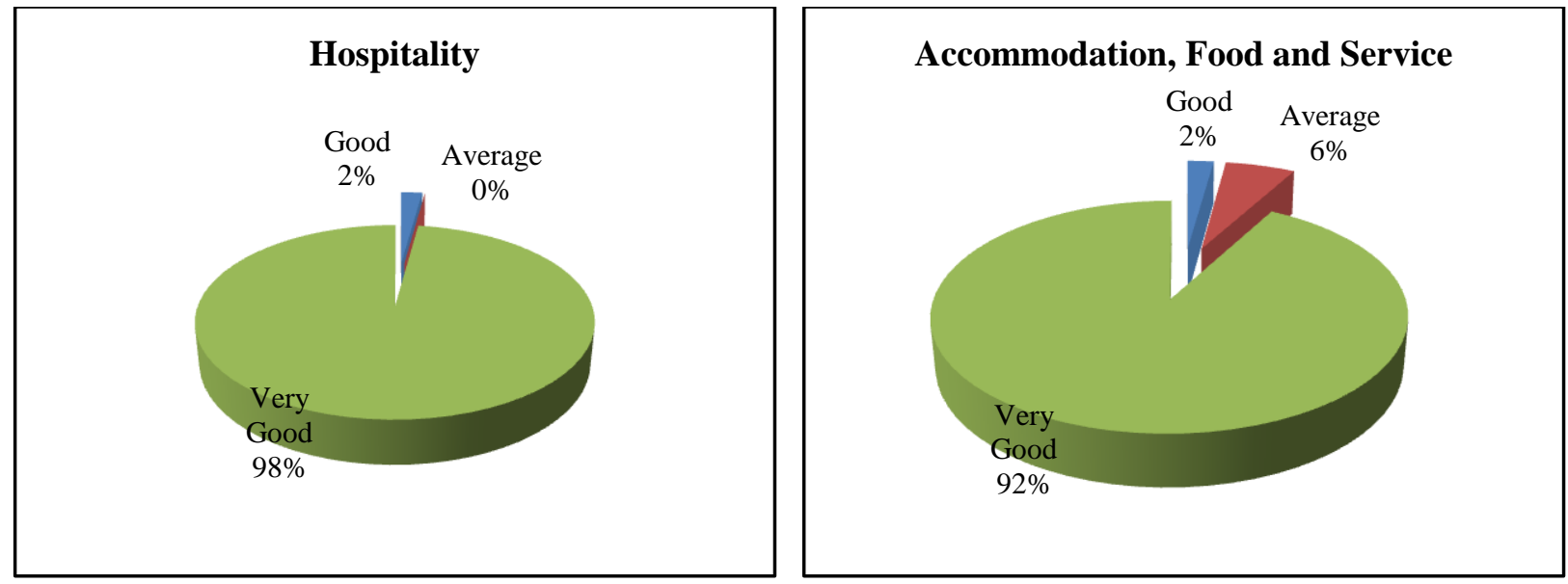

Figure 3. Geographical distribution of the visitors on percentage.

From Figure 3, we conclude that the hospitality appreciated by $98 \%$ of tourists with "Very Good", $0 \%$ 
"Average", and 2\% "Good", while the accommodation, food, and service valued by $92 \%$ of tourists with "Very Good", $6 \%$ with "Average", and 2\% "Good". The percentage of tourists who values with "Good", coincides with the number of visitors who do not return, which has been noticed by interviews with managers and owners of hotels and guesthouses.

(4) The number of tourists/visitors by year for the period 2006-2015.

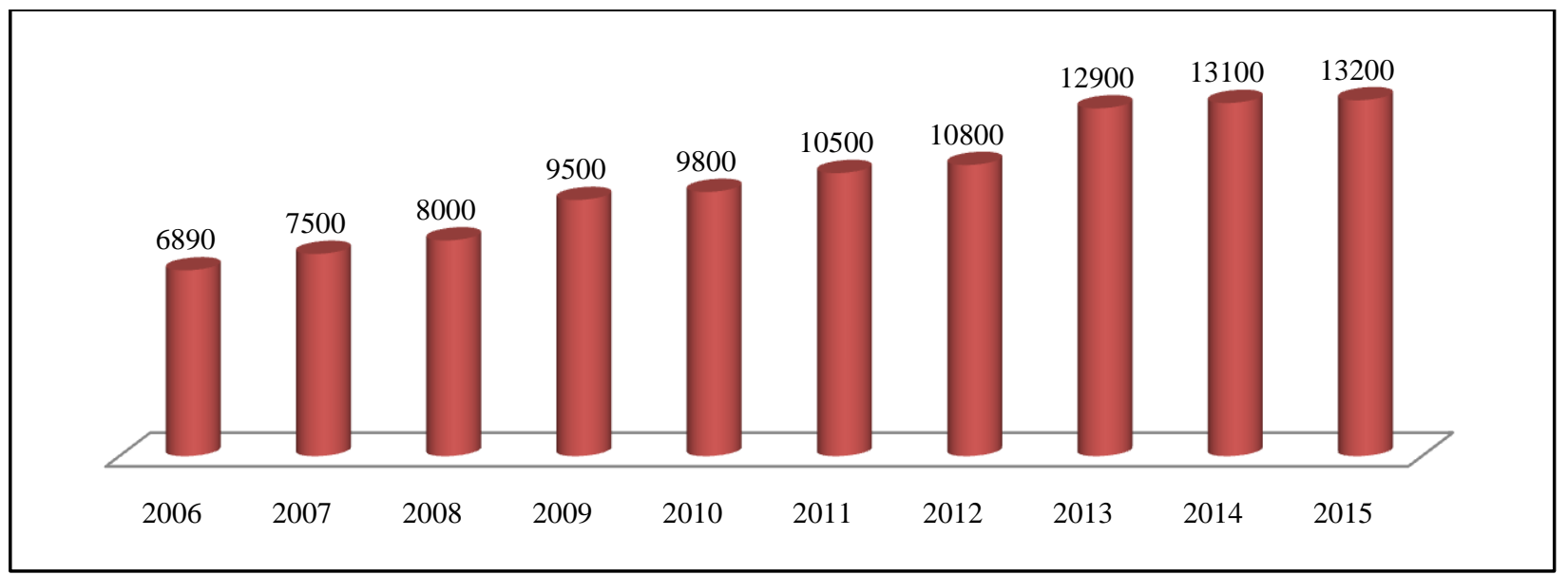

Figure 4. The number of visitors/tourists in years 2006-2015.

Figure 4 indicates that the number of visitors/tourists is growing. Increasing the number of visitors/tourists comes from increasing the number of hotels and guesthouses (See Figure 5).

(5) Number of beds in hotels and hostels.

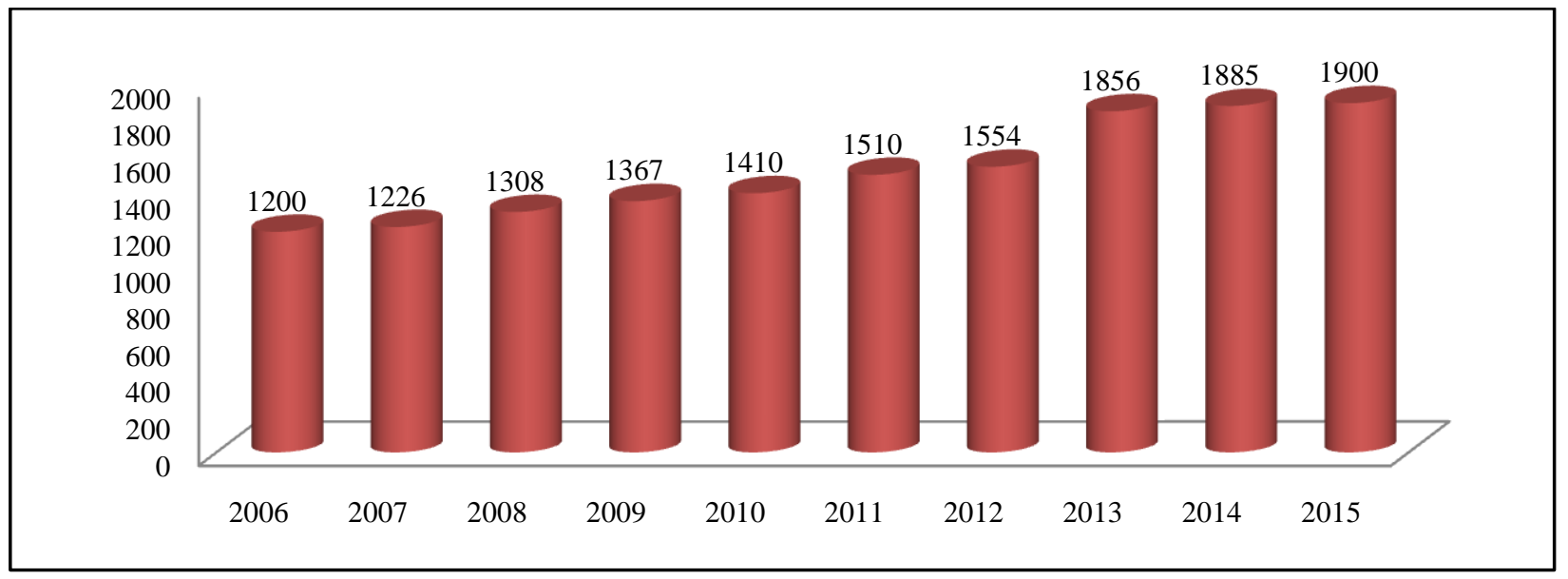

Figure 5. The number of visitors/tourists in years 2006-2015.

(6) Total revenues (hotels and hostels) in years 2006-2015.

From Figure 6, we conclude that the income from thermal waters tourism is growing. Income in 2015, compared to 2006 almost doubled, while total income for $2006-2015$ is $€ 1,004,102$. 


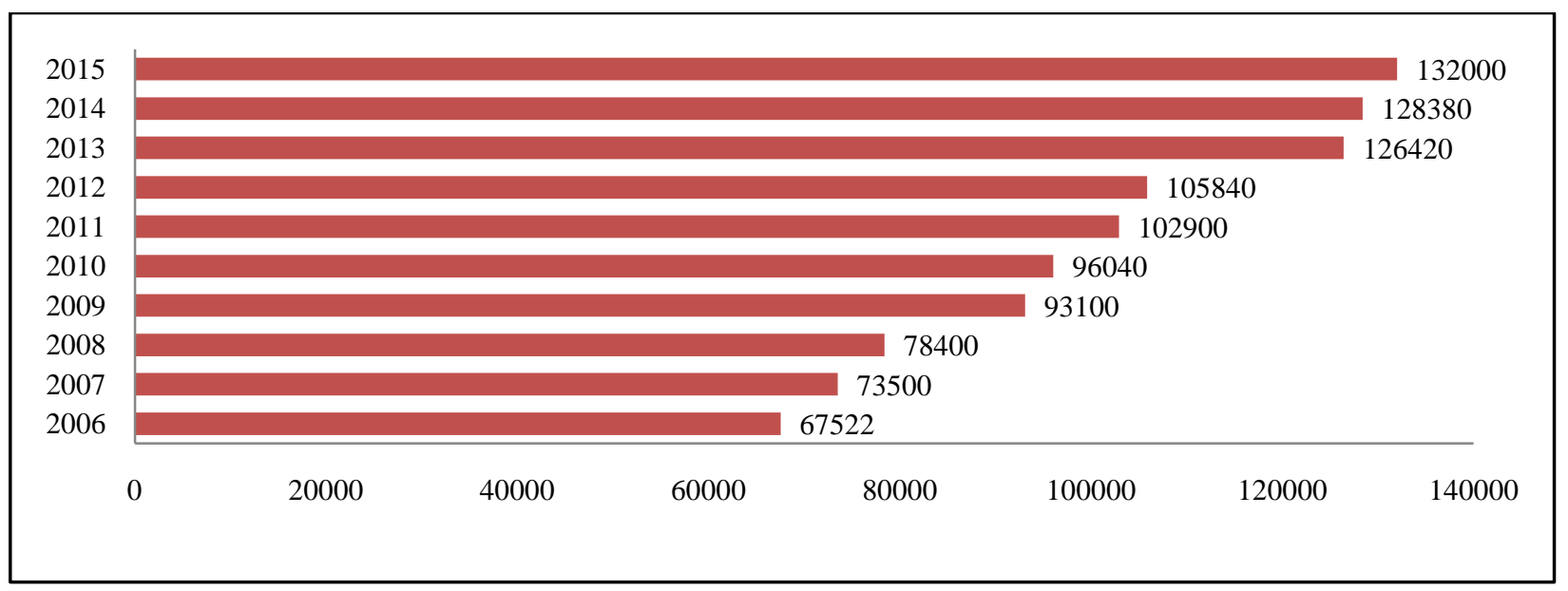

Figure 6. Income appropriations for 2006-2015.

\section{Estimates by the SWOT Analysis}

\begin{tabular}{|l|l|}
\hline Advantages & Weaknesses \\
(1) Thermal waters are a rarity in the world of the healing & (1) Garbage management; \\
power; & (2) Lack of information online; \\
(2) Nights of staying in minimum cost; & (3) Lack tourist guide; \\
(3) Hospitable and generous community; & (4) Lack of elite tourism for VIP persons; \\
(4) Quiet and safe area; & (5) Lack of shops that sell souvenirs; \\
(5) Very beautiful nature; & (6) Lack of small museums to tell the story of the area; \\
(6) Comfortable accommodation in hotels and hostels; & (7) Lack of restoration of the museum of national hero Gjergj \\
(7) Purity and traditional cooking; & Kastriot Skanderbeg Çidhën Dibër; \\
(8) Culture communication; & (8) Lack of paved roads to facilitate the movement of tourists in \\
(9) BIO products; & the whole area of Dibër. \\
(10) Variety of nature monuments; & \\
(11) Healthy climate; & \\
(12) Figures of national history3. &
\end{tabular}

Opportunities

(1) Greater interest by the Municipality of Diber in the creation of modern facilities in Balnear Centre and building capacity for tourist reception;

(2) The biggest interest of the government, development agencies and donors to invest in northeast Shqipëisë;

(3) Promotion and interest by the Ministry of Tourism about health tourism in thermal waters in Albania;

(4) The advantageous geographical position due to its proximity to Kosovo and Macedonia;

(5) Construction of apartments for VIP persons;

(6) BIO product development.

\section{Threats}

(1) Natural disasters such as fires and floods;

(2) Damaging natural and pristine places.

\section{Conclusions}

- Health tourism in the thermal waters at Peshkopi has affected the growth of revenue: (a) in hotel businesses and families who provide services in the tourism function; (b) the budget of the State Enterprise and the Peshkopi

\footnotetext{
3 And our national hero, Gjergj Kastriot Skanderbeg (Sinë, Dibër) and his contemporaries Mojsi Golem; The President of the League of Prizren, Ilyas Pasha Dibra (Kllopçisht, Dibër); The vice/prime minister of the Government of Ismail Qemali, Nikoll Kacori (Region-Lurë, Dibër); The King Zog (Burgajet, Mat, Dibër); The birthplace of the great poet and writer Migjeni; The great writer Haki Stërmilli (Great Dibër); The President's socialist system Haxhi Leshi (Great Dibër) and why can be debated because of the system (Murrja, 2008).
} 
municipality budget; (c) the agricultural businesses and farmers from selling their produce. Also, the development of tourism has brought (a) increasing employment and self-employment in Llixha neighborhood and its surrounding villages and (b) increasing prosperity in this community.

- The number of tourists every year has increased. This growth has attracted the attention of business leaders and residents investing in the construction of hotels and houses in the adoption of modern accommodation conditions.

- $98 \%$ of tourists appreciate the hospitality "Very good", $2 \%$ "Good", but accommodation, food, and service is valued by $92 \%$ with "Very good", $6 \%$ with "Average", and $2 \%$ "Good". The percentage of tourist, who appreciates the "Good", coincides with the number of visitors who do not return, which has been noticed by interviews with managers and owners of hotels and guesthouses.

- Missing:

(a) Road infrastructure to enable geography recognition of Dibër;

(b) Museums to recognize the history of Dibër;

(c) Apartments for VIP persons, to enable the development of elite tourism, according to international standardized assessments;

(d) Medium-term strategic development programs and long-term local government and central government.

\section{Recommendations}

Through this study, we recommend:

- Greater interest in promoting and increasing investment in health tourism in the thermal waters:

(a) The central government through the Line Ministries;

(b) Local government through the Municipality of Dibër;

(c) Domestic and foreign donors.

- Creating a database of national and local institutions for the number of tourists attending Peshkopi Thermal Baths.

- More interest on business evaluation for construction of hotels under international stars evaluation, to enable attendance of VIP persons.

- Increased investment by central and local government to improve the road infrastructure, historical, geographic.

- Improving infrastructure in Balnear complex.

\section{Reference}

Buwerman, B. L., O’Connell, R. T., \& Hand, M. L. (2001). Business statistics in practice (2nd ed.). NY: McGraw-Hill/Irwin. MTM (2018). Strategjia kombëtare për zhvillimin e qëndrueshëm të turizmit 2018-2022 (Draft). Ministria e Turizmit dhe Mjedisit. Tirane.

Draft-Strategjia Sektoriale e Turizmit 2013-2020, Agjencia Kombëtare e Turizmit.

Frashëri, K. (2012). "Historia e Dibrës” (Qё nga lashtësia deri në mars 1939). ISBN: 978-99956-04-82-0. Tiranë: Botime MetB. Girone, G., \& Salvemini, T. (2003). Lezione di Statistika. Tiranë, Albania.

INSTAT, (2017). Annual statistical report, 2017. Tirana, Albania.

Lind, D. A., Marchel, W. G., \& Wathen, S. A. (2008). Basic statistics for business \& economics (6th ed.). NY: McGraw-Hill.

Murrja, A. (2008). Zhvillimi i turizmit në rajonin e Dibrës. Revista Ekonomia dhe Tranzicioni, Qendra Shqiptare për Kërkime Ekonomike, Viti XIII, 129-142.

Murrja, A., Meço, M., \& Tomorri, I. (2016). Turizmi në Dibër nëpërmjet një eseje klasifikuese dhe vlerësimi sipas analizës 
SWOT. Naučni Bilten Buletini Shkencor Br/Nr. 8, viti, 166-176. E-ISSN 2337-0521 \& ISSN 1800-9794. Osmani, M. (2015). Metodat e statistikës. Tirane: Botimet Pegi.

http://shendeti.com.al/burimet-e-ujerave-termale-kurative-ne-shqiperi/ http://llixhat.ëeebly.com/

http://ëë.hoteleriturizemalbania.al/2012/05/burimet-e-ujerave-termale-kurative-ne.html http://ëëë.instat.gov.al/al/themes/turizmi.aspx?tab=tabs-5

http://bdcapa.com/historia/

http://shqiptarja.com/metroneës/2729/ujerat-termale-mes-pushimit-dhe-kurimit-119559.html

http://lixhat.com/sq/Contact

http://ëëë.bshz.ch/category/analiza/opinione/

http://about-albania.ëeebly.com/turizmi4.html

http://historia.shqiperia.com/iliret/lindja_dhe\%2Bkrijimi_bashkesive_primitive.php

http://gazetadielli.com/konferenca-e-londes-me-dy-vendime-per-shqiperine-sovrane-dhe-e- 